\title{
Arteriovenous Malformation in a Child with Extensive Involvement of the Mandible and Maxilla
}

\author{
Andrew L. Atkinson Augustine George Julie Long \\ Saba University School of Medicine, Saba, Netherlands Antilles
}

\section{Key Words}

Arteriovenous malformation · Mandible · Maxilla · Vascular tumor · Child

\begin{abstract}
Arteriovenous malformation of both the maxilla and mandible in a pediatric patient is a very rare phenomenon that carries with it a high mortality rate. Arteriovenous malformations, sometimes known as simple vascular tumors, can be present from birth or acquired over time due to trauma, surgery, or any kind of vascular manipulation of an area of the body.
\end{abstract}

\section{Introduction}

We present the case of an 11-year-old female patient who presented to her dentist's office with multiple loose teeth in her right maxilla. The dentist proceeded in extracting tooth No. 5 from the right maxilla. Following the extraction, there was massive hemorrhage from the site. The dentist manually held pressure on the site while an ambulance was called; estimated blood loss from the time of tooth extraction to arrival at the emergency room was over $2,900 \mathrm{~cm}^{3}$.

\section{Case Presentation}

A healthy 11-year-old Hispanic female with a negative medical history presented to the pediatric emergency room via ambulance with the dentist that extracted a tooth in his office still tamponading the site with gauze. The patient was taking no medications, and had never been hospitalized before; both the patient as well as her mother denied any head trauma in the past.

The history of the present illness started 3 weeks prior when she was taken to her primary care physician by her mother because of right facial swelling, superficial vein engorgement of the right side of the face, and hypertrophy of her upper right gingiva with occasional bleeding. She was treated with a 10-day course of amoxicillin, which according to the patient's mother did little to improve the swelling. 


\begin{tabular}{l|l|l|l} 
Cose Reports in & $\begin{array}{l}\text { Case Rep Neurol 2010;2:85-90 } \\
\text { D0I: } 10.1159 / 000316933\end{array}$ & Published online: June 19, 2010 & $\begin{array}{l}\text { @ 2010 S. Karger AG, Basel } \\
\text { ISSN 1662-680X } \\
\text { www.karger.com/crn }\end{array}$ \\
\hline
\end{tabular}

A week later, when she was taken to the dentist for her routine 6-month appointment, the dentist found that she had 3 loose teeth in her right maxilla. The dentist decided to pull the teeth; immediately after the first tooth extraction there was a flood of bright red blood that remained continuous.

In the pediatric emergency room, the patient presented with a blood pressure of 59/34 $\mathrm{mm} \mathrm{Hg}$ with a heart rate of $136 \mathrm{bpm}$. Five units of packed red blood cells were given; the patient was stabilized and a computed tomography (CT) scan was done. The CT scan revealed an interosseous arteriovenous malformation (AVM) within the inferior aspect of the right maxillary sinus, also involving the right hemimandible (fig. 1). Following intubation, she was taken to the neurointerventional radiology unit where she received embolization of the feeding vessels to her very large AVM. Following the embolization, her bleeding overall improved dramatically; a generous amount of Surgicel, FloSeal, and Evicel was packed into the open socket and finally the gingiva was closed with 3-0 chromic gut sutures. Brain MRI and MRA were performed, which showed embolization of the right external carotid artery, including the maxillary, facial and lingual branches. The vasculature appeared significantly less extensive compared to the earlier CT, although there was still asymmetric prominence of the superficial veins of the right side of the face.

The patient was successfully extubated after 2 days and transferred to a medical/surgical pediatric floor. She was eventually discharged after an 11-day stay in the hospital with strict discharge instructions on homecare and follow-up for surgery at a later date.

One week after discharge, the patient was brought to the pediatric emergency room with complaints of right hemispheric facial numbness, pain and weakness. Physical exam besides the facial palsy was unremarkable. Visual acuity was 20/20 bilaterally, with the ophthalmic exam showing no evidence of dilated or tortuous retinal vessels, ruling out AVMs of the eyes. The patient was worked up for rightsided facial palsy; an MRI scan was performed and revealed abnormal enhancement of the facial nerves on the right side within the temporal bone, indicating possible ischemia. The patient was started on Solu-Medrol and went in preparation for surgical intervention for a re-embolization of the AVM. The patient was taken to the operating room, the surgery ended up lasting a little over $25 \mathrm{~h}$. The AVM was found to have extensive mandibular and maxillary involvement (fig. 2). The AVM that was resected from the mandible measured approximately $4 \times 3 \mathrm{~cm}$, and the AVM resected from the maxilla was $4 \times 4$ $\mathrm{cm}$. The patient ended up having a hemimandibulectomy/hemimaxillectomy, and superficial parotidectomy with facial nerve dissection. Bone grafting reconstruction was performed with plating of both the maxilla and the mandible with placement of a collagen graft. During the procedure, the patient was given 9 units of packed red blood cells, 4 units of fresh frozen plasma, and 2 units of platelets.

\section{Discussion}

The detection rate of AVM in the general population based on prospective data from the New York Islands study is approximately 1.34 per 100,000 persons [1]. Death occurs in $10-15 \%$ of patients who have hemorrhage, and morbidity of various degrees occurs in approximately 50\% [2]. Mortality and morbidity rates are significant because of the fact that AVMs located in the head and neck region are clinically silent until they are manually manipulated or subjected to some sort of trauma and hemorrhage.

Imaging studies may help a practioner in identifying an AVM, but for screening purposes they are not indicated. Plain films may show either bony overgrowth or bone destruction to an area secondary to high blood flow. Bedside ultrasound can sometimes be used to locate high-flow lesions, but both plain films and ultrasound are poor tests to differentiate AVMs from other pathology such as hemangiomas. The most sensitive test is an MRI.

AVMs that have bled once are at a 9 times greater risk to hemorrhage again within one year if not surgically corrected the first time [3]. Surgical resection is mandatory because of the risk of recurrence. Embolization can be used preoperatively but not as a mainstay of treatment. Embolization is used for acute control of the bleeding, but not as primary treatment because of the chance of collateral circulation developing over time. The 
surgical procedure entails removing the entire AVM; if a part of the AVM is missed in surgery, the AVM will subsequently grow back in $100 \%$ of the cases.

A syndrome that always has to be in your differential when presented with AVMs of the head and neck is Wyburn-Mason syndrome, also known as Bonnet-Dechaume-Blanc syndrome. This is a rare nonhereditary phakomatosis characterized by congenital ipsilateral retinal brain (usually midbrain), and, less frequently, facial angiomas [4]. Thought to be a congenital disturbance in the formation of the vasculature of the mesoderm, this syndrome has scarcely been seen in medical literature since it was first described in 1937.

Whenever a practioner witnesses evidence of a retinal AVM (usually showing dilated and tortuous retinal vessels, most frequently from the superotemporal arcade), imaging of the head should follow. Though this syndrome is quite rare, there are no current screening protocols for AVMs, but ophthalmic exams are a routine part of patient care. The problem, however, presents itself in the management of asymptomatic AVMs found incidentally. Until better information becomes available, asymptomatic intracranial AVMs discovered after identification of retinal AVMs should be approached exactly as one would approach isolated asymptomatic intracranial AVMs, which have an estimated rupture rate of $2.2 \%$ per year [5]. For cerebral AVMs, a considerable body of evidence continues to support treatment in many asymptomatic patients against just simple observation [6]. 


\begin{tabular}{l|l|l|l} 
Case Reports in & $\begin{array}{l}\text { Case Rep Neurol 2010;2:85-90 } \\
\text { Dol: } 10.1159 / 000316933\end{array}$ & Published online: June 19, 2010 & $\begin{array}{l}\text { ○ 2010 S. Karger AG, Basel } \\
\text { ISSN 1662-680X } \\
\text { www.karger.com/crn }\end{array}$ \\
\hline
\end{tabular}

Fig. 1. Large AVM with adjacent hemorrhage from tooth extraction. Note the mandibular ramus bone remodeling from the long-standing AVM on the right side.

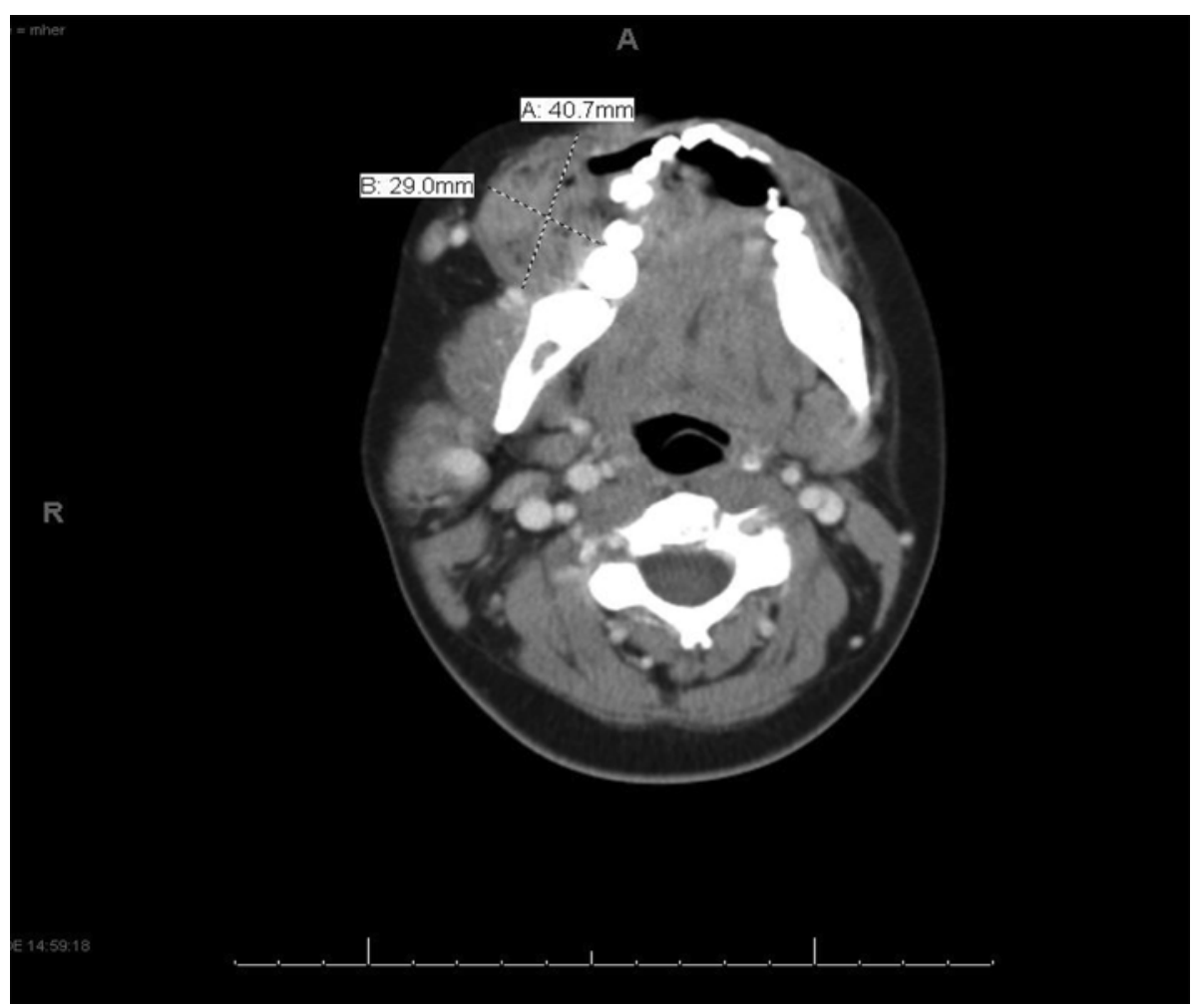




\begin{tabular}{l|l|l|l}
$\begin{array}{c}\text { Cose Reports in } \\
\text { Reulviojy }\end{array}$ & $\begin{array}{l}\text { Case Rep Neurol 2010;2:85-90 } \\
\text { D0I: 10.1159/000316933 }\end{array}$ & Published online: June 19, 2010 & $\begin{array}{l}\text { O 2010 S. Karger AG, Basel } \\
\text { ISSN 1662-680X } \\
\text { www.karger.com/crn }\end{array}$ \\
\hline
\end{tabular}

Fig. 2. Exposed mandible. Note the hyperdense areas on the bone where the AVM was resected. The mandible on the right side had to be removed secondary to capillary infiltration into the bone.

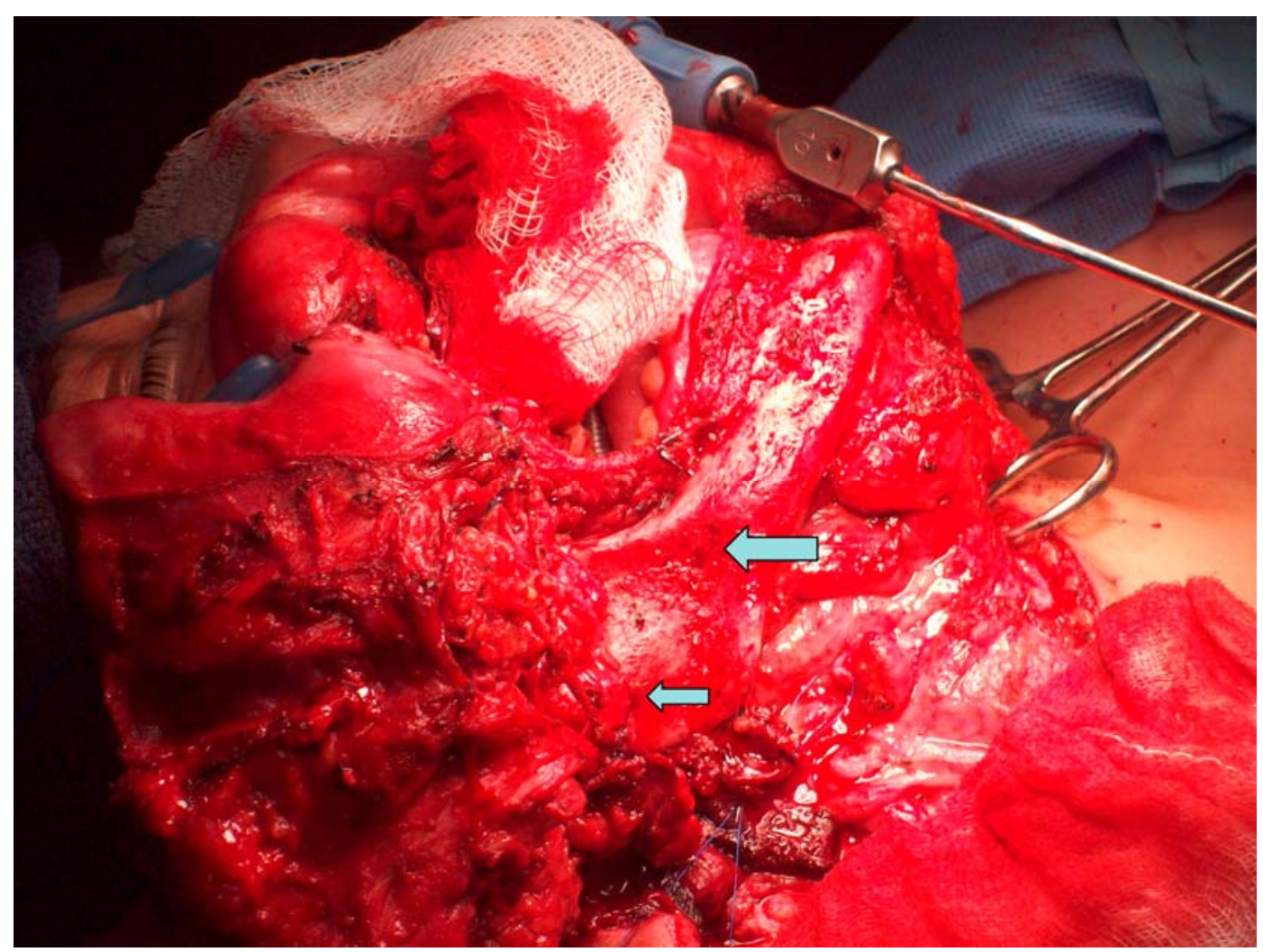




\section{References}

1 Stapf C, Mast H, Sciacca RR, Berenstein A, Nelson PK, Gobin YP, et al: The New York Islands AVM Study: design, study progress, and initial results. Stroke 2003;34:29-33.

2 Weston-Schumacher H, Marshall R: Arteriovenous Malformations. Emedicine 2010. http://emedicine.medscape.com/article/1160167-overview (accessed March 2010).

3 Arteriovenous Malformations (and Other Vascular Lesions of the Central Nervous System). MedicineNet.

http://www.medicinenet.com/arteriovenous_malformation/article.htm (accessed March 2010).

4 Drozdowski W, Iwanowski P, Walecki J, Borowik H: Wyburn-Mason syndrome. Case report of unusual ipsilateral hemiparesis following subarachnoid hemorrhage. Neuro-Opthamology 2002;28:35-40.

5 Brown RD Jr, Wiebers DO, Forbes G, et al: The natural history of unruptured intracranial arteriovenous malformations. J Neurosurg 1988;68:352-357.

6 Cockroft K: Unruptured brain arteriovenous malformations should be treated conservatively. Stroke 2007;38:3310-3311. 